\title{
Role of Green Accounting in Developing India
}

\author{
Ishpreet Kaur Saini \\ PG-Manipal University Jaipur
}

\begin{abstract}
Green Accounting is the route which is followed towards the sustainable future. The sustained level of income which is achieved without depleting the Natural Assets of the Nation is through Green Accounting. When the Economic Damages are considered with respect to the exhaustion of Natural Resources while determining the Income of the nation it is known as Green Accounting. The main objective of the study is to understand the role played by Green Accounting in the development of the Indian Economy and also its objectives, stages, form, need and challenges. Methodology of the paper is based on the secondary sources with respect to the role played by green accounting in developing India. The paper is a conceptual research paper. Willingness of adopting green accounting is not enough, it must be done also. Knowledge regarding the importance of green accounting is not enough, must be applied in the working as well. Just the urgency of doing is not sufficient, everything must be brought into action as well.
\end{abstract}

Key Words: Green Accounting, Environmental Accounting, Sustainable, Indian Economy

\section{INTRODUCTION}

Money is not the only factor for calculating the income or expenditure of the country. The use of natural resources is another important aspect. In order to surround ourselves with the assets and not the liabilities Green Accounting emerges. When the Economic Damages are considered with respect to the exhaustion of Natural Resources while determining the Income of the nation it is known as Green Accounting. It is the sustained level of income which is achieved without depleting the Natural Assets of the Nation.

India as still in the phase of developing is focusing on various factors out of which one factor is Environmental Awareness. In order to spread Environmental Awareness what more is needed is to have a proper prove by maintaining a proper account for the environment as well.

Various steps are taken by various sectors of the country to protect and promote the healthy green environment so as to protect the near future and in order to have proper records for these steps a new branch of accounting is introduced which is known as Green Accounting.

Green Accounting can be replaced by many other terms such as Environmental Accounting or Resource Accounting or even as Integrated Accounting.

Professor Peter wood is the one who introduced the term Environmental Accounting in 1980s.

Green Accounting or Resource Accounting deals with maintaining accounting records for the well-being of the environment. It is totally a new aspect of the accounts still its growing due to its importance as recognised as relevant.

\section{REVIEW OF LITERATURE}

- $\quad$ Cormier \& Irene (2001), An Examination of social and environment reporting strategies: - The study dealt with the disclosures relating to the society and environment. It gave a conclusion that the costs and benefits of environmental disclosures does not deal with the relationship relating to social disclosures.

- Gamini Herath (2005), Sustainable development and environmental accounting: The challenge to the Economic and Accounting Profession: - This study tries to use the natural resource accounting instead of the gross domestic product for the welfare of the nation which has various drawbacks. All the difficulties were considered while measuring the environmental damage.

- $\quad$ Gupta, Aruna Das (2007), Social responsibility in India towards Global compact approach: - The research was based upon the trends of the social responsibility in India and concluded that these Trends are encouraging and also very important/significant in India.

- $\quad$ N Navya \& Yamini Apoorva, Green Accounting and its role in developing India: - This study concluded that the environmental accounting is helpful in decision making and if India successfully adopts it, It may start growing at a more faster pace. Also the government need to make amendments in this aspect and check that all these are being also complied with. 


\section{OBJECTIVE}

The main objective of the study is to understand the role played by green accounting in the development of the Indian Economy and also its objectives, stages, forms, needs and challenges.

\section{METHODOLOGY}

This paper is a conceptual research paper to conceptualise the concept of green accounting and also the role it plays in the development of Indian Economy. The data has been collected from various Secondary sources.

\section{ANALYSIS}

Green Accounting is the route followed towards the sustainable future. The system used by green accounting is The System of Environmental Economic Accounting (SEEA). The focus of the resource accounting is to protect the resources which are scarce and also prevent the depletion of environment.

India is a developing country and so it has to face a duel problem that is of protecting the environment as well as developing the economy. No choice is to be made and both are to be considered and work upon together.

\subsection{Measurement of GGDP}

When from the conventional GDP the environmental cost of that specific financial year is deducted, we reach to GGDP that is the Green Gross Domestic Product or Green GDP.

Green GDP helps in the measurement of the climate change and depletion of resources in the monetary terms. The equation of calculating GGDP is: -

\section{GGDP = GDP - Net Natural Capital Consumption}

\subsection{Objectives of Green Accounting}

- $\quad$ Segregation of all environment related stock and flow: This objective leads to identification of the part of the gross domestic product of the country that considers the significant costs relating to the environment which gave a negative impact towards the economic growth.

- $\quad$ Correspondence of physical resource accounting with the monetary resource accounting: This objective leads to the conversion of every physical resource into the monetary aspect of the resources so as to take it into account while calculating the National Income.

- Evaluation of environmental costs and benefits: Another objective is to evaluate the cost with respect to the depletion of resources in production as well as final demand stage and also the changes occurring in the environment quality.

- Maintenance of tangible wealth: It takes into account not only the human wealth but the wealth related to the environment so as to reach to the Net domestic product (NDP) including environmental aggregates.

\subsection{Stages of Green Accounting}

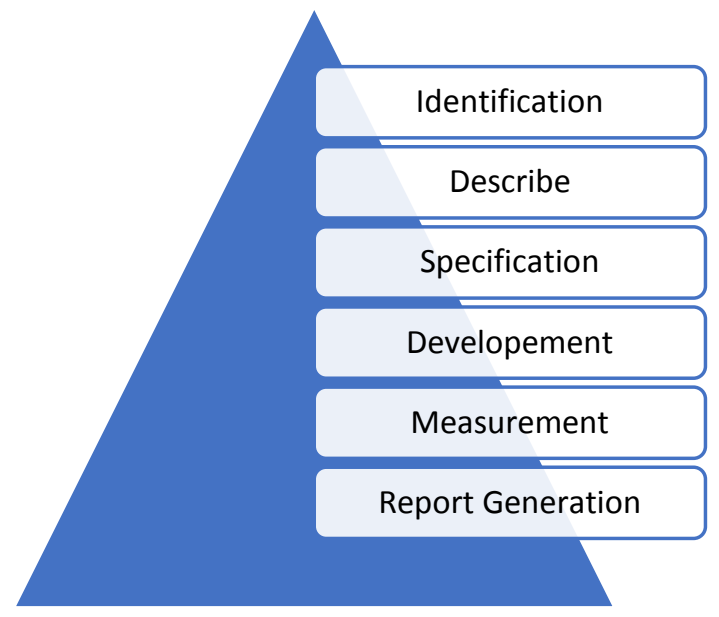


International Journal of Advanced Research in Computer and Communication Engineering

Vol. 10, Issue 10, October 2021

DOI: $10.17148 /$ IJARCCE.2021.101005

- Identification: This is the first step in the accounting process to identify the policies, cost, benefits, liabilities, targets, disclosures relating to the environment.

- Describe: The next step is to describe the factors identified so as to use them for the measurement of the environmental Performance.

- $\quad$ Specification: The next step is to identify the targets with respect to the environment for short term as well as long term.

- Development: Development of indicators is an important step wherein these indicators represent the environmental performance.

- $\quad$ Measurement: In this step the measurement of actual performance is done and comparison is made with the standard performance.

- $\quad$ Report Generation: Finally the report is generated based on the result so as to know what further can be done.

\subsection{Forms of Green Accounting}

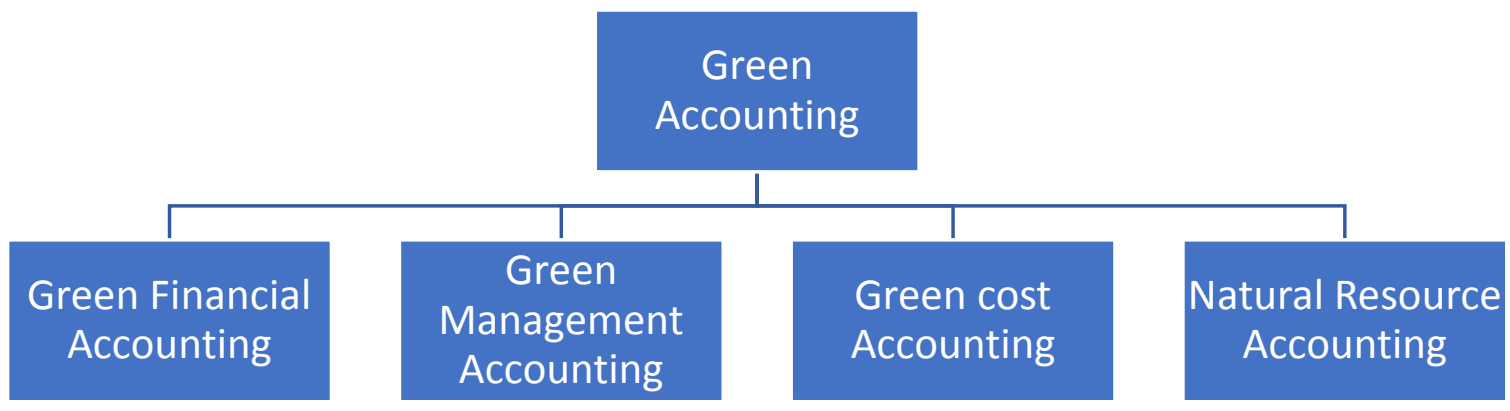

- Green Financial Accounting: This Accounting focuses upon the environmental aspect in the end of the year through the financial statements.

- $\quad$ Green Management Accounting: This Accounting involves the management of the Environmental as well as economic performance. It involves all types of planning with respect to the environmental management.

- $\quad$ Green Cost Accounting: This Accounting deals with the evaluation of the overall environmental cost. It involves the total social costs as well as private costs.

- Natural Resource Accounting: It is used while computing National Income with the inclusion of all environmental aspects which is termed as Environmental Gross National Income.

\section{Needs of Green Accounting}

\section{Pollution Control}

\section{Sustainable Developement}

\section{Environmental Management System}

\section{Environmental Performance}


- $\quad$ Pollution Control: Green Accounting by having proper records help in controlling the pollution at a large level. - $\quad$ Sustainable Development: Green Accounting is a step towards the sustainable future by a proper environmental management.

- $\quad$ Environmental Management System: Green Accounting provides an environment centred management system with which proper records can be achieved related to the dimension of the environment.

- Environmental Performance: Green Accounting helps in assessing, testing and recording the performance of the activities of the environment.

\subsection{Challenges of Green Accounting}

- It is a Long-term process and so reaching the conclusion is a difficult task.

- Green Accounting is really good but theoretically only, practically it requires major actions.

- Not all resources can be covered under this as conversion of everything into quantitative terms becomes difficult. - Green Accounting does not have a standard accounting method so the comparison between firms or countries will be difficult.

\section{CONCLUSION}

Green Accounting is a special chance with which India can stay ahead of British Heritage in order to create a new India which will not be a developing but a developed country. Green Accounting arouse because its not just a benefit or revenue which we get by the natural resources but somewhere someone pays for the environment also thus creating a dual aspect. India needs to make a choice between protecting our environment or just let it be destroyed and not a choice between protecting our environment or our economy as the environmental protection will gradually lead to the development of our country. Willingness of adopting Green Accounting is not enough, it must be done. Knowledge regarding the importance of Green Accounting is not enough, it must be applied in the working as well. Just the urgency of doing is not sufficient everything must be brought into action as well. Accounting is the language of business and green accounting is the language of the environment via business. Green Accounting is an important aspect and can't be ignored as it not only covers the environment information but also the economic information. Incorporation of green accounting at National level would lead to the development of the Indian Economy.

\section{SUGGESTIONS}

- $\quad$ Awareness must be spread about the concept and need of green accounting to the general public as well.

- Maintaining green accounting records must be made mandatory for all organisation and government must take strict actions against it.

- Annual reports must also carry the information regarding the environmental accounts.

- A proper accounting framework must be developed for the purpose of green accounting.

\section{REFERENCES}

1. Agarwal Varsha, L Kalpaja; International Journal of Advance Research, Ideas and Innovations in Technology ISSN: 2454-132X Impact factor: 4.295 (Volume 4, Issue 5) Available online at: www.ijariit.com A study on the importance of green accounting

2. GREEN ACCOUNTING - A NEW CHALLENGE FOR ACCOUNTING SYSTEM AND RESPONSIBILITY TOWARDS ENVIRONMENT Sunitha.S Assistant Professor, New Horizon College

3. IOSR Journal of Business and Management (IOSR-JBM) e-ISSN: 2278-487X, p-ISSN: 2319-7668 A Study on Green Accounting and Its Practices in India 1N Anil Kumar, 2T Sai Pranitha, 3N Kiran Kumar

4. IOSR Journal of Business and Management (IOSR-JBM) e-ISSN: 2278-487X, p-ISSN: 2319-7668 Green Accounting and its Role in Developing India N Navya1, PVSN Yamini Apoorva2

5. IRJA-Indian Research Journal, Volume: 1, Series:2. Issue: March, 2014 ISSN: 2347-7695 ADVANTAGES OF IMPLEMENTING GREEN ACCOUNTNG (Within an economic entity) Author Dr. BHAWANA REWADIKAR

6. International Journal for Research in Applied Science \& Engineering Technology (IJRASET) ISSN: 2321-9653; IC Value: 45.98; SJ Impact Factor: 6.887 Volume 6 Issue II, February 2018-Environmental Accounting Reroting Practices in India- Issues and Challenges V. Vijaya Lakshmi1, K. Syamala Devi2

7. Philip Kotler, Gary Armstrong, Prafullah Y. Agnihotri, Ehsan ul Haque, Principles of Marketing: a South Asian Perspective (Tamil Nadu: Pearson India Education Services Pvt Ltd, 2001)

8. Dr. Preeti Malik (Assistant Professor) and Dr. Alka Mittal (Reader) Maharaja Surajmal Institute "A Study of Green Accounting Practices in India” IRACST - International Journal of Commerce, Business and Management (IJCBM), ISSN: 2319-2828 Vol. 4, No.6, December 2015

9. Ramesh, L, M.Com., "A Study of Environmental Accounting Practices in selected Indian Companies" \{Phd research study\}.

10. http://www.yourarticlelibrary.com/economics/environmental-economics/green-accounting-need-objectives-problems-and-otherdetails $/ 39675$

11. https://www.techjini.com/blog/green-accounting/ 